\title{
ETNOGRAFSKA BAŠTINA: IZAZOVI U MUZEJSKIM PREDSTAVLJANJIMA
}

\begin{abstract}
Sažetak
U radu se prikazuju izdvojeni primjeri u pripremi i realizaciji novog stalnog postava Gradskog muzeja Virovitica otvorenog 2019. godine, pri čemu je osobit naglasak stavljen na predmete Etnološkog odjela koji imaju zadaću približiti svakodnevni život 19. i 20. stoljeća u Virovitici i okolnom području. Predstavit će se muzejski predmeti baštinskog značenja novom kontekstualizacijom unutar postava s jedinstvenom temom i zajedničkom pričom objedinjenih zbirki. Muzejska koncepcija nazvana Drveno doba sadržava teme o drvu kao izvorno korištenom materijalu od prapovijesti do današnjih dana. Muzejske predmete ( $\mathrm{u}$ izravnoj i neizravnoj vezi s drvom) tako se povezuje sa svakodnevnim životom i ljudskim djelovanjem različitim temama vezanima uz rad, identitet, privređivanje, obitelj, stanovanje, društveni život, vjerovanja te umjetničko izražavanje. Rad se dotiče i muzejskih izazova u odabiru i pripremi predmeta, oblikovanju manjih priča radi približavanja materijalne i nematerijalne baštine te postavljanja građe i muzeografskih promišljanja unutar zaštićenog spomenika kulture - dvorca Pejačević.
\end{abstract}

Ključne riječi: stalni postav; etnografska baština; muzejski predmeti.

\section{Početak obnove}

Nalazeći se pred opsežnom obnovom dvorca Pejačević ${ }^{1}$ u sklopu integriranog europskog projekta 5 do 12 za Dvorac, kustosi Gradskog muzeja Virovitica dobili su zahtjevan zadatak predstavljanja muzejske građe i predmeta u novom prostoru. ${ }^{2}$ Upravo su ideja i muzeološka studija, nastale u suradnji muzeja s tvrtkom KREAR ${ }^{3}$, omo-

1 Dvorac koji tlorisno ima oblik izduženog pravokutnika nalazi se u središtu grada na povišenom platou. Graditelji i prvi vlasnici, obitelj Pejačević, dovršili su ga početkom 19. stoljeća na temeljima srednjovjekovne utvrde (usp. Šćitaroci, 1998: 325). Dvorac je barokno-klasicistička građevina koja je uzore imala u srednjoeuropskim tradicijama.

2 Naziv projekta nastao je iz alarmantne potrebe za sanacijom i obnovom vanjskog i unutrašnjeg prostora.

3 KREAR d.o.o. Zagreb čine muzeologinja Natalija Bajs i arhitekt Javier Luri, koji su bili zaduženi za projekt muzeografskog opremanja dvorca Pejačević i za projektantski nadzor. 
gućile odobrenje projekta koji je sufinancirala Europska unija sredstvima Europskog fonda za regionalni razvoj. ${ }^{4} \mathrm{U}$ sklopu projekta obnovljen je dvorac te su revitalizirani i uređeni gradski park i šetnica. U obnovljenom dvorcu novim stalnim postavom virovitički je muzej želio napraviti iskorak u interpretaciji i prezentaciji povijesne, kulturne i prirodne baštine virovitičkoga područja. Važan segment muzeološke koncepcije bio je odabir pristupa predstavljanja predmeta i građe. Iz općeraširenog i uvriježenog koncepta postava u muzejima zavičajnoga tipa ${ }^{5}$ koji se temelji na predstavljanju zbirki kronološkim redom, pristupilo se muzeološkoj koncepciji temeljenoj na jedinstvenoj temi. Rezultat je bila promjena poimanja muzeja i njegovih temeljnih zbirki - kako u lokalnoj zajednici, tako i unutar same institucije. Fokus na predstavljanju predmeta, a ne zbirki, pridonio je razvijanju tematskog scenarija koji posjetitelje/korisnike uvodi u narativ podijeljen na nekoliko dijelova. Osmišljena je priča o drvu temeljena na sljedećim činjenicama: prva je vezana uz povijesni značaj i geografski smještaj grada obgrljenog šumama; druga se tiče brojnosti predmeta i građe (od drva) unutar zbirki koje su trebale biti predstavljene; treća je vezana uz drvoprerađivačku industriju, koja je gospodarski osnažila grad. Drvo je tako predstavljeno u odnosu s čovjekom u interpretaciji ljudskog ekosustava na širem području, a s aspekta materijalne i nematerijalne baštine uključujući kulturno-povijesno, prirodno i ekonomsko gledište.

Poštujući značajke ustanove kao muzeja zavičajnoga tipa sa specifičnim smještajem u povijesnom spomeniku kulture, usporedno se razvijao i koncept postava Povijest grada i Dvorca. Dvorac kao prvi izložak i nedjeljiv dio identiteta Gradskog muzeja Virovitica predstavljen je predmetima i građom o srednjovjekovnoj utvrdi te pričom o kulturnopovijesnom razvoju središta grada. Predmeti od prapovijesti do suvremenog doba koji su oblikovali grad i njegovu okolicu predstavljeni su kronološki u četirima cjelinama određenima povijesnom 1234 . godinom ${ }^{6}$ te dopunjuju koncepciju drvenog doba.

Muzeološka koncepcija obranjena je 2019. pred Hrvatskim muzejskim vijećem ${ }^{7}$ te je dobila pozitivno mišljenje za realizaciju koja je dovršena svečanim otvorenjem zgrade i stalnih postava 5. prosinca 2019. Cjelokupni izložbeni prostor i vizualizaciju unutar dvorca odlikuje grafički dizajn koji prati muzejski postav o drvu i pripadajuće cjeline. ${ }^{8}$ Zanimljivo rješenje vizualnog identiteta koncepcije drvenog doba vezano uz temu drva provedeno je na svim etažama dvorca i daje karakteristična obilježja projektu.

4 Vrijeme trajanja projekta: 25. 8. 2016. - 25. 8. 2019.

5 Prešutna su očekivanja lokalne zajednice da muzej takvog tipa predstavi svoju zavičajnu građu određenim slijedom, čime bi se zadovoljila forma prikaza povijesti sredine. Zbog terminološke nedosljednosti kod zavičajnih i gradskih muzeja, česta je zabuna pri definiranju svrhe i rada (Radovanlija Mileusnić, 2001: 19), iz čega nije izuzet ni Gradski muzej Virovitica.

6 Godine 1234. herceg Koloman izdao je Virovitici ispravu (povelju) kojom stanovnicima daruje prava i povlastice. To je najstarija isprava grada (Horvat, 2001: 8).

7 Koncepciju potpisuju Mihaela Kulej, Natalija Bajs i Javier Luri. Suradnici su stručni djelatnici muzeja.

8 Grafički dizajn postava potpisuje Bilić_Müller Studio. 


\section{Interdisciplinarnost}

Odabir teme za postav i prezentaciju cijelog muzeja temeljen je na prepoznatljivosti i potrebi prirodnog materijala toga područja. Univerzalnošću teme željelo se postići izdvajanje centralne niti vodilje koja bi objedinila raznovrsnu građu zastupljenu u zavičajnom tipu muzeja. Na taj način predmeti i građa stvaraju autentičnu priču koja može pobuditi interes i identifikaciju različitih profila korisnika.

Postav Drveno doba zamišljen je kao koncept podijeljen u tri cjeline s određenim temama i podcjelinama. Obitelj, privređivanje i zajednica osnove su prema kojima se podijelio postav. Prva cjelina, $\mathrm{Za}$ istim stolom, obrađuje teme vezane uz pojedinca i obitelj kao temeljnu društvenu jedinicu. Druga cjelina, Ruke majstora, posjetitelje uvodi u temu privređivanja, koje su u virovitičkom kraju oslanjalo na drvo radi stjecanja sredstava za život, dok treća, Da kucnem o drvo... zlo ne čulo!, predstavlja teme društvenog života i zajednice unutar koje pojedinci ostvaruju suživot i dijele određene društvene i duhovne vrijednosti.

Pri odabiru predmeta i muzejske građe za novi postav nastojalo se zadovoljiti nekoliko kriterija. Prvi se odnosio na kulturno i povijesno značenje predmeta za Viroviticu i okolno područje. Željelo se predstaviti predmete koji mogu snažno ispričati povijesne priče zanimljive budućim posjetiteljima. Ostali kriteriji bili su: vrsta materijala i povezanost s drvom u prenesenom značenju, zatim složenost predmeta i njegova mogućnost integriranja u širi kontekst priče. Svakako je važno bilo i mjesto korištenja predmeta, odnosno njegova uporaba, vrijeme nastanka i specifičnost u izradi, odnosno ručno oblikovanje. Ti kriteriji doveli su do konačne verzije postava u kojoj su, vodeći računa o interdisciplinarnosti, odabrani predmeti svih zbirki virovitičkog muzeja. Cjeline tako sadržavaju arheološke i povijesne te etnološke i umjetničke predmete koji zajedničkim postavom stvaraju sadržajno kvalitetan narativ.

Etnološki odjel sadrži razmjerno velik broj predmeta izrađenih od drva (Jurković Petras, 2018: 4), a koji su se koristili u godišnjim i životnim običajima. Samorazumljivo je da to nije isključiva osobitost virovitičkoga kraja ni zbirki etnografskog sadržaja, ali je odraz načina očuvanja ručno obrađenih, izrađenih i korištenih predmeta koje je čovjek upotrebljavao u raznim životnim situacijama. Zbog navedenoga, zastupljenost etnografskih predmeta u oblikovanju stalnog postava nešto je veća, iako se sadržajno nastojalo korisnicima ne nametati podjelu na odjele i zbirke. Kao dobar primjer interdisciplinarnosti Galerijskog i Etnološkog odjela izdvojila bih primjer predstavljanja umjetničkog rada Igora Rufa, rodom Virovitičanina. Prateći cjelinu tradicijske gradnje i upotrebu drva kao temeljnog materijala u gradnji kuća i gospodarskih zgrada, izdvojen je njegov rad Wunderschön iz 2010. godine. Riječ je o svjetlosno-zvučnom objektu načinjenom od drva, medijapana i pleksiglasa. U njega 
su inkorporirani rasvjeta i zvuk koji se aktivira pomoću senzora. ${ }^{9}$ Objekt oblikom podsjeća na čardak, građevinu koja na seoskim imanjima služi kao spremište za kukuruz. ${ }^{10}$ Na taj način nastojalo se sadržajno povezati muzejske predmete i interpretirati ulogu drva u prošlosti i suvremenosti.

\section{Primjeri iz virovitičkog muzeja}

Tijekom priprema za znanstveno-stručni skup Tradicijska kultura istočne Hrvatske: povijest $i$ suvremenost $\mathrm{u}$ sklopu izlaganja u studenome 2019. predstavljeno je svega nekoliko primjera iz prakse jer je muzej bio pred otvorenjem i u završnim poslovima. Ovaj rad donosi dopunu izlaganja i druge primjere unutar postava, a kojima se potvrđuje način komunikacije i suvremeniji pristup etnografskoj građi i odnosu s korisnicima/posjetiteljima.

Nastojanja u prevladavanju izazova u predstavljanju materijalne i nematerijalne baštine te uspješnost rješenja u svladavanju suvremenih muzeoloških zahtjeva oprimjerit će se i pojasniti putem opisa cjelina, muzejske građe i načina kreiranja doživljaja posjetiteljima.

\section{Nematerijalna baština: govor Virovitice}

Ako se želi predstaviti dio zavičajne baštine, neizostavni su dio identiteta starosjedilaca grada Virovitice Mikeši. Radi se o nekadašnjim stanovnicima čiji se naziv vjerojatno oblikovao pri susretima s doseljenim Česima u 19. stoljeću, a koji su kao razlikovnu osnovu za domicilne žitelje grada uzeli naziv prepredenog mačka Mikeša iz češke usmene predaje. ${ }^{11}$ Bavili su se kirijašenjem, odnosno izvlačenjem trupaca iz šume. U zasebnoj cjelini pod nazivom Svjedoci grada, osim na materijalnu građu i predmete, željeli smo naglasak staviti i na njihov govor, koji obiluje tuđicama iz turskoga, njemačkoga, češkoga i mađarskoga jezika. Taj dio nematerijalne baštine predstavljen je na dva interaktivna zaslona na dodir s ponuđenim sadržajima zvučnih zapisa govora izvornih govornika mikeštine i zaslona na dodir (dodirnik, touch screen) s ponuđenim sadržajima. Nematerijalna etnografska baština poput govora tako je dostupna korisnicima pomoću novih tehnologija na kojima su

9 Iz njih dopire glas gospodina Fulira, lika iz filma Tko pjeva zlo ne misli Kreše Golika. Zvuk je montiran tako da se u različitim vremenskim intervalima ponavlja „To je wunderschön...wunderschön...”

10 Uzorak objekta preuzet je s ruševne građevine koja je bila dio kafića na uglu Klaićeve i Austrijske ulice u Zagrebu. Iako sagrađen nakon tridesetih godina prošlog stoljeća, jedan je od posljednjih spomenika tog vremena i atmosfere.

11 Josef Lada (1887. - 1957.) bio je češki slikar, ilustrator, scenograf i pisac. Objavio je bajkovitu knjigu Mačak Mikeš 30-ih godina 20. stoljeća temeljenu na usmenim pričama pričljivog i dobroćudnog mačka koji doživljava brojne zgode. 
zastupljene tri skupine značajnih čuvara mikeštine na zvučnim zapisima. ${ }^{12} \mathrm{Nji-}$ hov govor i odabrane teme iz svakodnevnog života posjetitelje sadržajno uvode u svijet zavičajne baštine. Teme o crticama iz grada, zaprežnim kolima i karakteru domaćeg stanovništva odabrane su kako bi posjetiteljima približile konstruirani identitet grada kojega lokalno stanovništvo Virovitice čine Mikeši. Na drugome interaktivnom zaslonu na dodir predstavljeni su sadržaji s igrom za djecu i odrasle kojima se približavaju mikeške riječi. Posjetitelji mogu odabrati križaljku s mikeškim riječima, dječju slagalicu predmeta na lokalnom i standardnom jeziku, kao i igru povezivanja fraza lokalnog i standardnog govora.

\section{Stari recepti i posude}

Cjelina građanske i seoske prehrane predstavljena je pod naslovom Za istim stolom. Različite osjetilne poticaje, koji prate namirnice, hranu i jela, predstavili smo predmetima i vizualizacijom nekadašnjeg obiteljskog stola u građanskoj i seoskoj sredini. Stol kao centralni dio predstavljanja prehrane ovoga kraja nenametljive je crne boje, a dijeli ga zrcalo, čime je postignut efekt prostornosti. Muzejski rukopisni zapisi, recepti i fotografije spravljenih jela predstavljeni su na zaslonu na dodir. Ponuđeni monitor osim pretraživanja, razgledavanja i edukacije nudi i prenošenje dijela muzejskih sadržaja. Tako se prezentirani recepti mogu putem aplikacije poslati elektroničkom poštom. Na istom ekranu mogu se i digitalno pretraživati kataloške jedinice izloženih predmeta u špajzi (smočnici, ostavi). Uz izložene muzejske predmete ponuđen je i pregled prema namjeni, pa se oni mogu pretraživati prema nekoliko vrsta namirnica. Grupirani predmeti Arheološkog, Etnološkog i Kulturnopovijesnog odjela smješteni $u$ istu cjelinu podijeljeni su prema namjeni na posude za vodu, ulje, ocat, kiselinu, vino, mlijeko, vrhnje, pekmez i mast. Etnografsko keramičko posuđe, zemljeni lonci, različitih su oblika, funkcija i namjena (Jurković Petras, 2012: 14) te čine bogati dio te izložbene cjeline. Posuđe na neutralnoj polici nudi pregled od pretpovijesnog doba do sredine 20. stoljeća, čime se svjedoči osobitostima prehrambenih navika različitih kulturno-povijesnih razdoblja. Imajući na umu edukaciju mladih posjetitelja, pripremljena je i igra pamćenja (memory), koja nudi sjene i oblike izloženih posuda te njihove nazive. Originalni izloženi predmeti kontekstualizirani su interaktivnim sadržajima koji nude širu edukaciju o predmetu, kao i vizualni digitalni input novim generacijama posjetitelja.

12 Najstariji je Tomislav Terzić, autor popularne radioemisije Mikeš na lokalnoj radiopostaji, potom ga nasljeđuje dvojac Mijo Pavelko i Draško Zidar s emisijom Mikeš i Prco te i danas aktivni Dragutin Celić Crni. 


\section{Kosa mi se vije}

Materijali vezani uz načine djevojačkog češljanja, ženskog pokrivanja glave, kao i izrada ženske kapice poculice tehnikom čipke na batiće predstavljeni su tekstom, fotografijama i videomaterijalom. Zaslon je vizualno uklopljen kao dio izložbene cjeline kojim se dopunjuje osnovni tekst. Prikazan je film Magija kose ${ }^{13}$ te video s demonstracijom izrade čipke na batiće. ${ }^{14}$ Tradicijsko češljanje virovitičkoga kraja posjetiteljima je učinjeno dostupnim i putem zasebnog zida za fotografiranje. Radi se o transparentnoj stijenci s ocrtanim djevojačkim frizurama i oglavljima. Na taj način, osim zabavnog karaktera i stavljanja korisnika/posjetitelja u uloge djevojaka i žena s nekadašnjim frizurama, ponuđen je autentični vizualni izgled tradicionalnih oglavlja virovitičkoga područja specifičan po čeonoj izradi na kapici tehnikom čipke na batiće (Jurković Petras, 2016).

\section{Dobro osnovano, pola otkano}

U sklopu cjeline privređivanja s krovnim naslovom Ruke majstora izložen je dio etnografskih predmeta iz kućne radinosti. Osnovna ideja te cjeline bila je ponuditi posjetiteljima linearan prikaz napretka rukotvorskih vještina od samoukih do školovanih i izučenih majstora te približiti drvo od prvotnih potreba za kućanstvo s primjerima kućne izrade i razvoja obrtništva s primjerima drvenih alata i oruđa korištenih za svakodnevnu upotrebu u zajednici. U tom smislu uz izložene originalne predmete ponuđen je zaslon s prikazom brojnih ručno oblikovanih drvenih predmeta iz tradicijskoga gospodarskog života. Videozapis je dopuna originalnim drvenim predmetima karakterističnima za pripremu niti za tkanje, kao i složenom procesu proizvodnje domaćega platna na tkalačkome stanu. Video nudi fotografije iz Zbirke etnografske dokumentacijske građe i popratni tekst.

\section{Društvenost u kolu}

Prateći temu postava, pristupilo se i trećoj tematskoj cjelini koja obrađuje zajednicu, a nosi naziv Da kucnem o drvo... zlo ne čulo!. Drvo zasigurno nije prisutno u ljudskom životu isključivo kao sirovina koju čovjek koristi za oblikovanje i definiranje svog materijalnog svijeta već u njemu pronalazi posrednika za ispunjavanje svojih društvenih i duhovnih potreba. Upravo se drveće u mnogim svjetskim kulturama, pa i u kulturama na našem području, smatralo utjelovljenjem snage života i vitalnosti. Teme društvenog života iz Etnološkog odjela predstavili smo kolom, najraširenijim plesnim izričajem karakterističnim za južnoslavenske narode. Rekonstrukcija majpama ${ }^{15}$ omogućila je prikaz stabla u običajima. Narodne nošnje postavljene su u

\footnotetext{
13 Magija kose naziv je videoprikaza ženskog tradicijskog češljanja i pokrivanja kose u virovitičkome kraju. Film je izdan 2013. u nakladništvu Gradskog muzeja Virovitica. Traje $10 \mathrm{~min}$.

14 Video je nastao u sklopu projekta Čipkanje u Muzeju 2016. godine (Jurković Petras, 2016).

15 Majpam je proljetni običaj podizanja visokog drveta $(15-25 \mathrm{~m}) \mathrm{s}$ malenom krošnjom ukrašenom vrp-
} 
valjkaste vitrine koje su dio zamišljene kružnice kako bi se posjetitelji mogli „,uhvatiti u kolo“ i na taj način osjetiti ravnopravnost i snagu društvenog plesa. Također, putem zamišljene kružnice i kola promatrač može uočiti seosku odjeću kako se to i činilo u tradiciji. Osim videozida s prikazom plesa u kolu ovoga kraja, obrisi lutaka u narodnim nošnjama predstavljaju dobru pozadinu za fotografiranje.

\section{Glazbeni instrumenti}

Nastavljajući se na cjelinu narodnog kola i nošnji, posjetiteljima je omogućeno i slušanje tradicijskih pjesama na klupi. Interaktiv je zamišljen kao svojevrstan predah na kojemu se mogu poslušati pjesme iz sela i grada. Po osam odabranih zapisa pruža individualan uvid $\mathrm{u}$ dio nematerijalne baštine. Iz etnografske baštine odabrane su četiri pjesme koje se izvode $u$ kolima, dva instrumentala i dvije pjesme koje izvode pjevačke skupine, ženska i muška. ${ }^{16}$ Svojevrsni plošni interaktiv pruža i zid s fotografijama narodnih nošnji i ispisanim deseteračkim stihovima s temom šume i drva. Te kratke i šaljive pjesmice s rimom (svatovci i bećarci) nude posjetiteljima zabavan uvid u dio narodne društvenosti.

\section{Nekadašnja vjerovanja}

Vjerovanja u drveće dio su mitologije, bajoslavlja slavenskih naroda, a posebno se izdvaja sveprisutni mit o Stablu svijeta i sukobu božanstava Peruna i Velesa. Do današnjih dana očuvan običaj paljenja vatri (krijesa) u okolici Virovitice na Ivanjsko navečerje, odnosno Ivanje (24. lipnja) dovodi se u vezu s božanskom svadbom, Stablom svijeta i mijenom godišnjih doba. To je prikazano tekstom, predmetima i zapisom na zaslonu. Dio godišnjih običaja koji se isprepliću s drvom na fizičkoj i simboličkoj razini ispričani su predmetima u vitrini. Kao dodatni sadržaj ponuđen je videozapis na zaslonu sa slušalicama sa sadržajima vjerovanja oko Ivanja. Posjetiteljima se tako videosadržaj nudi kao dopuna predstavljene sadržajne cjeline.

\section{Interaktivi kao sadržajna dopuna}

Virovitički muzej nastojao je ovim projektom i novim stalnim postavom osuvremeniti predstavljanje predmeta i raznovrsne građe brojnim interaktivima i multimedijom. Sedam navedenih primjera povezano je s etnografskom građom i cjelinama, dok su ostali povezani s predmetima drugih zbirki. Primjeri korištenja multimedije istaknuti su kao sadržajna dopuna muzejskim pričama unutar cjelina stalnog postava. Na taj način dodatno je obogaćena forma cjelokupne koncepcije, čime je neupitno do-

cama, trakama, voćem, slatkišima i flašom, kao nagradom za najspretnijeg momka, često ispred kuće ili u centru sela. Običaj je raširen u kontinentalnom dijelu, a pristigao je iz srednjoeuropskih zemalja. Česta su plesna kola i zabave kraj podignutog drveta.

16 Snimke pjesama ustupila je Miroslava Hadžihusejnović Valašek, koja je krajem 20. stoljeća snimila društva. 
dana vrijednost kvaliteti muzejskog predstavljanja. Odabir građe iz zbirki Etnološkog odjela pokazao je kako se i materijalna i nematerijalna baština mogu predstaviti suvremenim oblikom korištenjem novih medija u drugačijem obliku. Digitalizacija građe donosi bolju preglednost i omogućuje lakše manipuliranje podatcima, čime se baštinske vrijednosti, u ovom slučaju etnografske građe, približavaju i omogućuju veću dostupnost. Primjer mogućnosti slanja rukopisnog recepta elektroničkom poštom dobar je pokazatelj na koji način etnografska građa može biti dostupnija i korisnija posjetiteljima. ${ }^{17} \mathrm{Uz}$ muzejske predmete, dodirnici predstavljaju dobrodošlu dopunu koja korisnicima omogućuje odabir, vrstu i količinu podataka koju žele doznati.

Zasebnu cjelinu interaktivnog dijela muzejskog postava čini i višejezični audiovodič. Interaktivnim muzejskim vodičem, koji je danas često korišten u muzejima, postiže se potpuno iskustvo prikaza predmeta, kao i snažniji doživljaj muzeja. Jednostavno korištenje tableta (dlanovnika) omogućuje preslušavanje pripremljenih tekstova cjelina koji se dopunjuju legendama u postavu. Time posjetitelj može slojevitije doživjeti muzej i stalni postav.

\section{Zaključak}

Novi pristupi u izlaganju predmeta u stalnom postavu uz korištenje interaktivne multimedije omogućuju korisnicima snažniji doživljaj predmeta i kontekstualizaciju etnografske građe. Uz originalne predmete, i virtualni prikazi putem multimedije omogućili su prenošenje baštine aktivnostima usmjerenima na edukaciju, zabavu i funkcionalnost. Ulaganjem $u$ infrastrukturu i suvremeno muzeografsko opremanje omogućuje se dostupnost većeg broja predmeta, što će u konačnici potencijalno osigurati širi raspon korisnika. Stoga se isplati uložiti u nove buduće projekte stalnih postava muzeja, koji će omogućiti digitalno predstavljanje građe i predmeta pohranjenih u muzejskim čuvaonicama. Time bi digitalizirani sadržaji mogli poslužiti kao koristan materijal kojim se obogaćuje rad na daljinu i u učionicama (ups. Jelavić-Petrović, 2019: 52). Korištenje i predstavljanje sadržaja na novim medijima približuje korisnicima ponuđene informacije i omogućuje im jednostavnije i lakše korištenje. Zasigurno će i buduće izložbe (povremene, pokretne i tematske), obogaćene sve popularnijim QR kodovima, pridonijeti popularizaciji suvremenih tehnoloških uređaja i alata u muzejskoj zajednici. Impresivni doživljaji ostvaruju se i korištenjem proširene stvarnosti (VR), za koju se koriste popularne naočale. Do tada se mogućnosti poput piljenja trupaca i praćenje procesa putem zaslona radi uživljavanja u proces sječe, kirijanja i nekadašnjeg teškog rada, kao i omogućavanje taktilnog doživljaja tekstura u procesima obrade drva (kora, sječka, piljevina, hoblovina), mogu smatrati kvalitetnim primjerima interaktivnosti.

${ }_{17}$ Velik dio recepata za slanje prikupljen je u sklopu projekta Mikeški jestvenik te je objavljen $\mathrm{u}$ istoimenoj knjižici. Usp. Jurković Petras-Mihaljević, 2017: 9-76. 


\section{Literatura}

Horvat, Rudolf (2001.) Povijest grada Virovitice, Matica hrvatska Virovitica.

Jelavić, Željka - Petrović, Anastazija (2019.) Što smo naučili u proih sto godina? Stoljeće muzejske edukacije u Etnografskom muzeju, u: Etnološka istraživanja, 24, Zagreb, 37-60.

Jurković Petras, Jasmina (2018.), Da kucnem o drvo: muzejski predmeti iz Etnološkog odjela virovitičkog muzeja, u: Sjedi drvo na drvo, katalog izložbe, Muzej Đakovštine i Gradski muzej Virovitica, Virovitica.

Jurković Petras, Jasmina (2012.), Zemljani lonci - virovitičko lončarstvo i lončarski proizvodi u Muzeju, katalog izložbe, Virovitica.

Jurković Petras, Jasmina - Mihaljević, Ljubica (2017.), Mikeški jestveni - knjižica recepata, Virovitica.

Jurković Petras, Jasmina (2016.), Čipkanje u Muzeju!, Gradski muzej Virovitica, Virovitica.

Maroević, Ivo (2005.), Razine muzealizacije vezane uz kulturnu baštinu, u: Informatica museologica 36 (3-4), Zagreb, 44-49.

Radovanlija Mileusnić, Snježana (2001.), Ustroj i organizacija knjižnica zavičajnih muzeja u Hrvatskoj, u: Museologija 38., Muzejski dokumentacijski centar, Zagreb.

Šćitaroci, Mladen i Bojana (1998.): Dvorci i perivoji u Slavoniji - od Zagreba do Iloka, Zagreb.

\section{Prilozi}

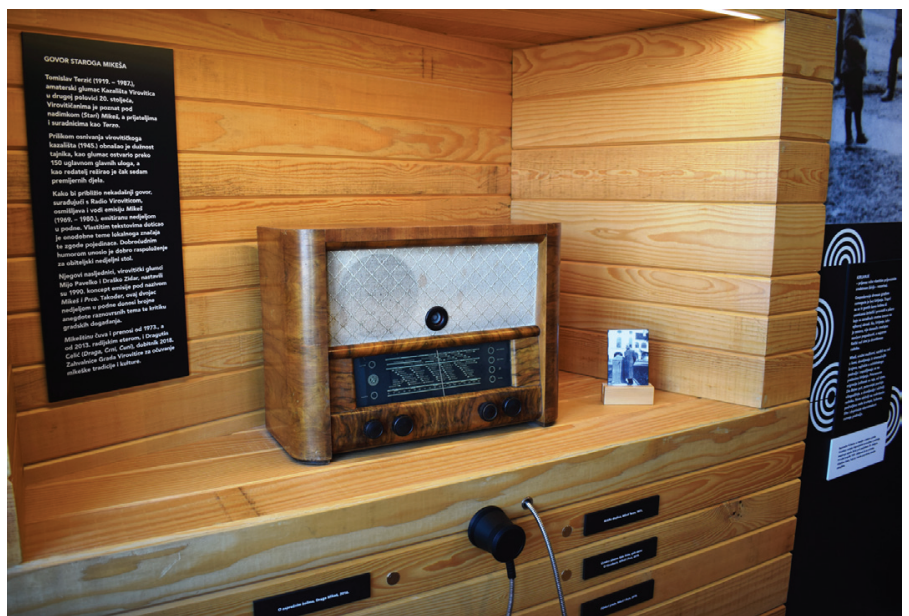

Slika 1. Interaktiv za slušanje Mikeškog govora. GMVT, 2019. 
Radovi Zavoda za znanstveni i umjetnički rad u Požegi, 9 (2020), str. 97-110

J. Jurković Petras: Etnografska baština: izazovi u muzejskim predstavljanjima

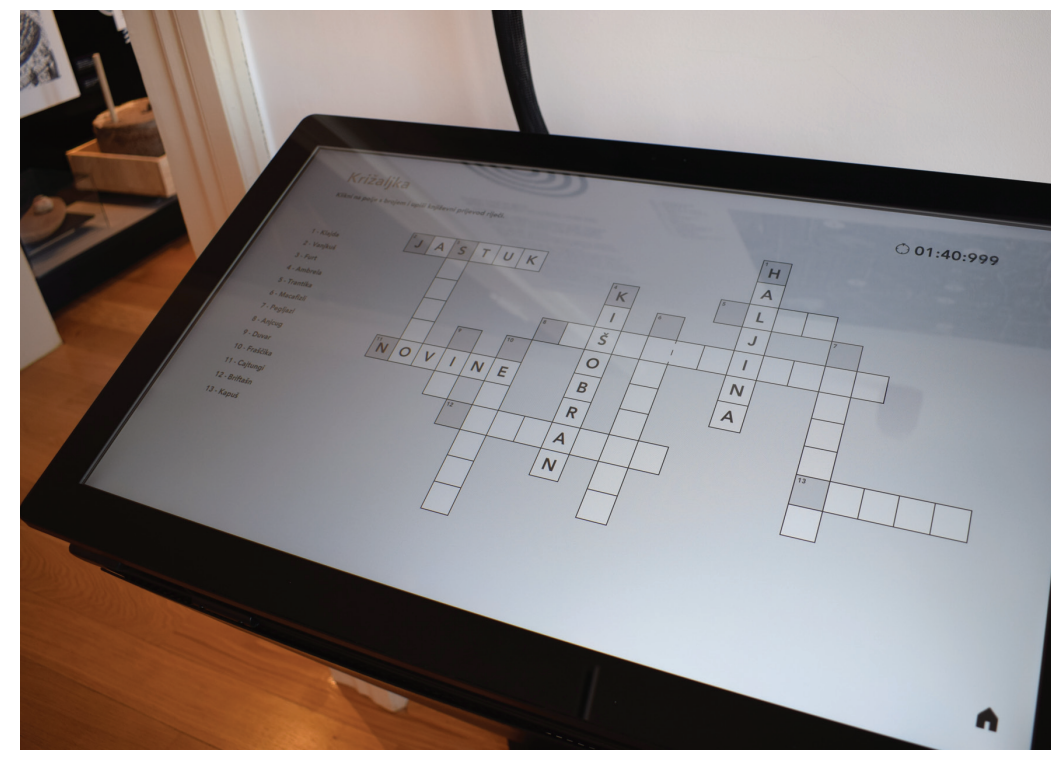

Slika 2. Igra riječima - Mikeška križaljka. GMVT, 2019.

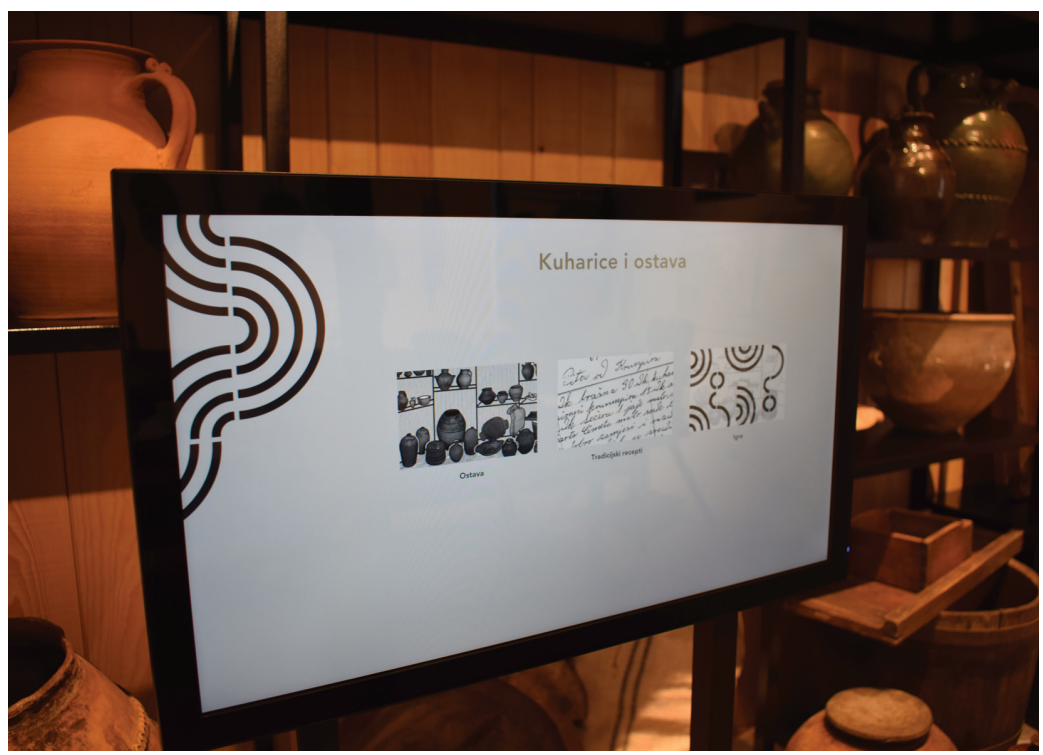

Slika 3. Prikaz multimedije u dijelu „Okusi nasljeđa“. GMVT, 2019. 


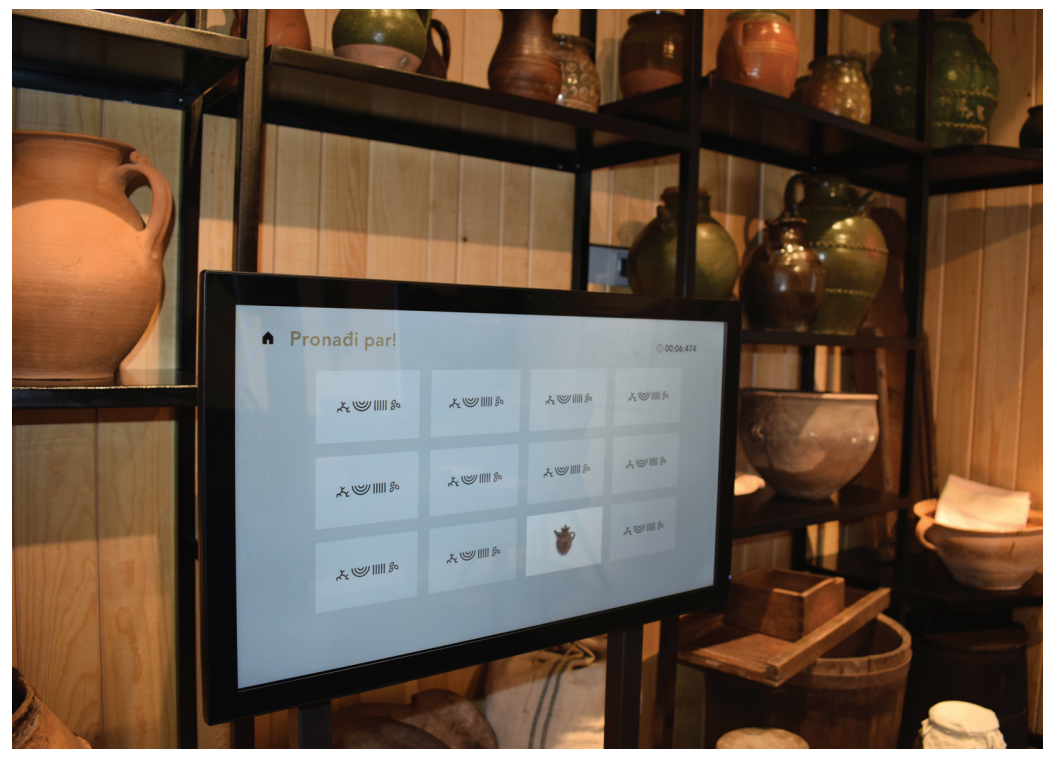

Slika 4. Jedna od tri ponuđenih igara u dijelu o prehrani. GMVT, 2019.

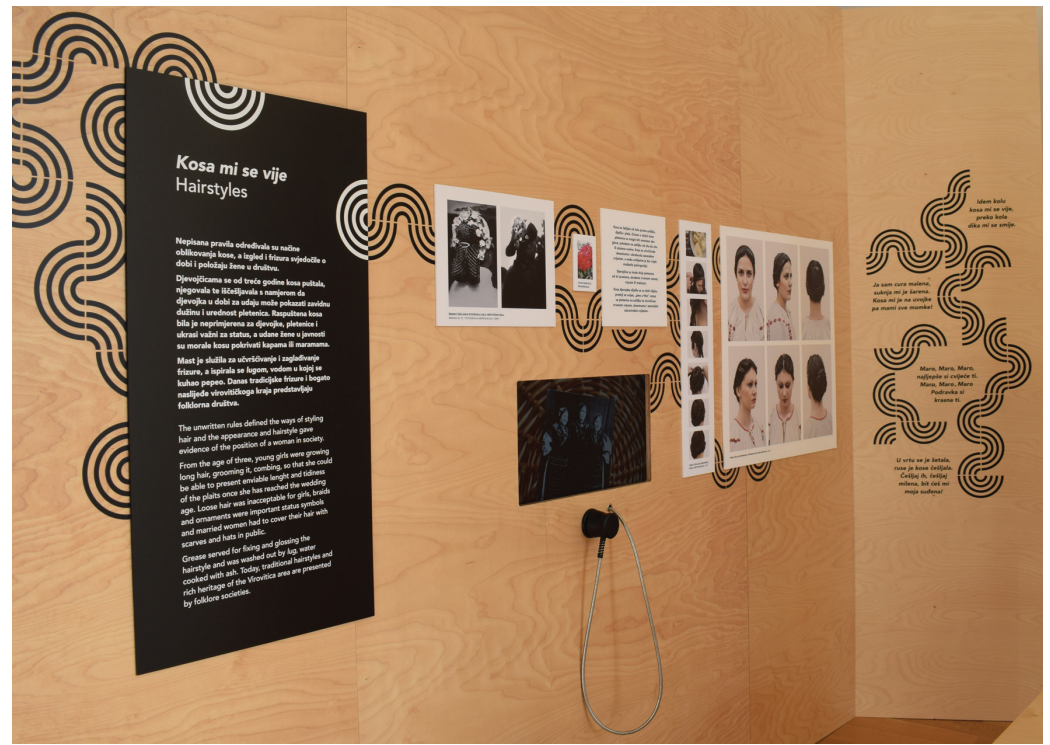

Slika 5. Film o ženskom češljanju. GMVT, 2019. 


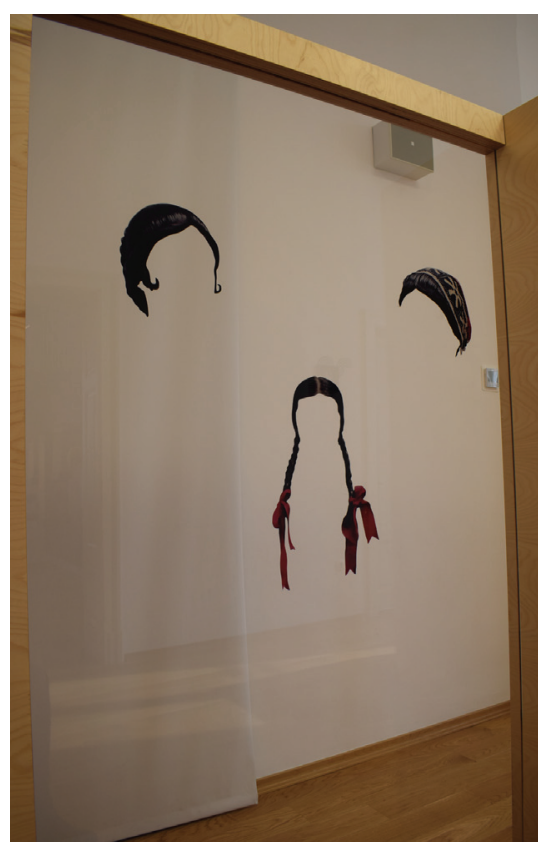

Slika 6. Zaslon za fotografiranje sa frizurama. GMVT, 2019.

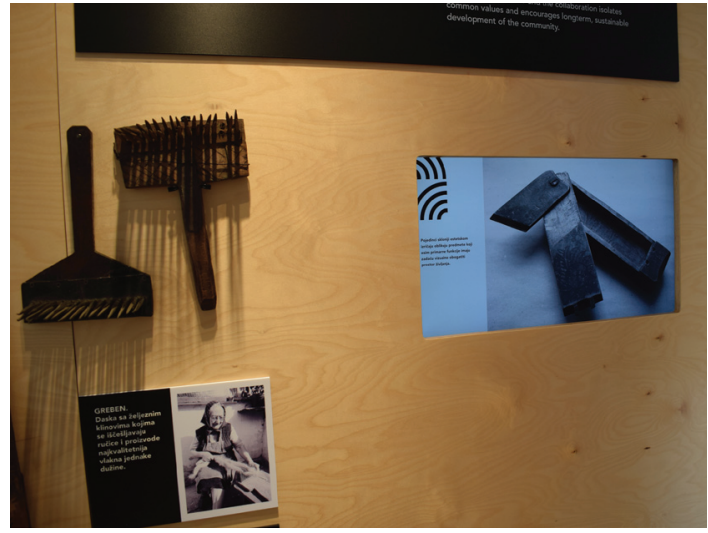

Slika 7. Ručno izrađeni drveni predmeti u cjelini "Ruke majstora". GMVT, 2019.

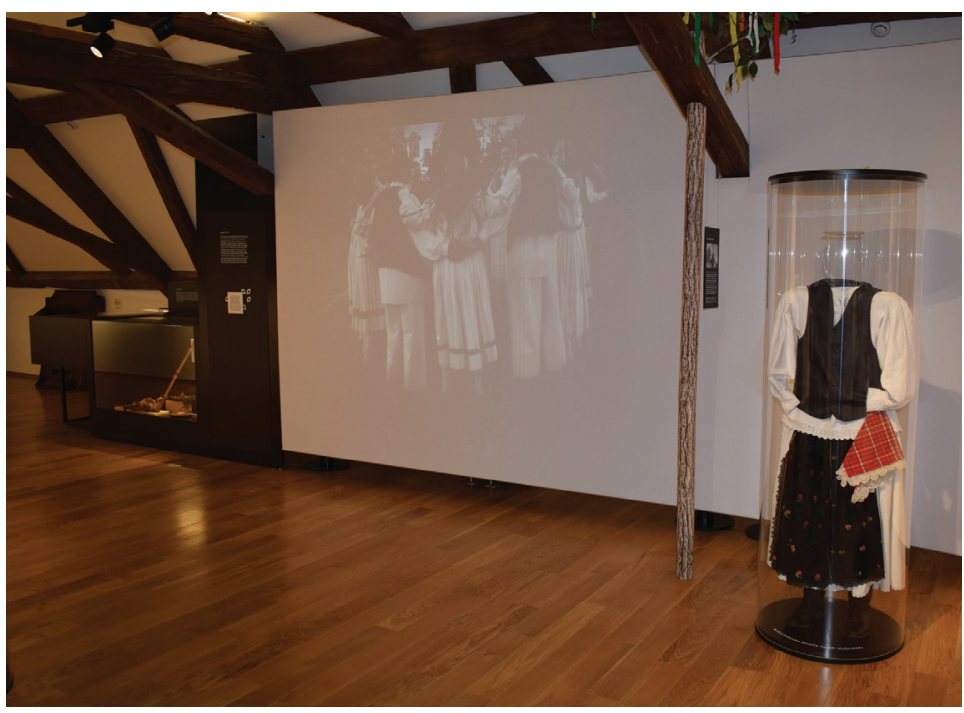

Slika 8. Projekcija plesa u kolu. GMVT, 2019. 


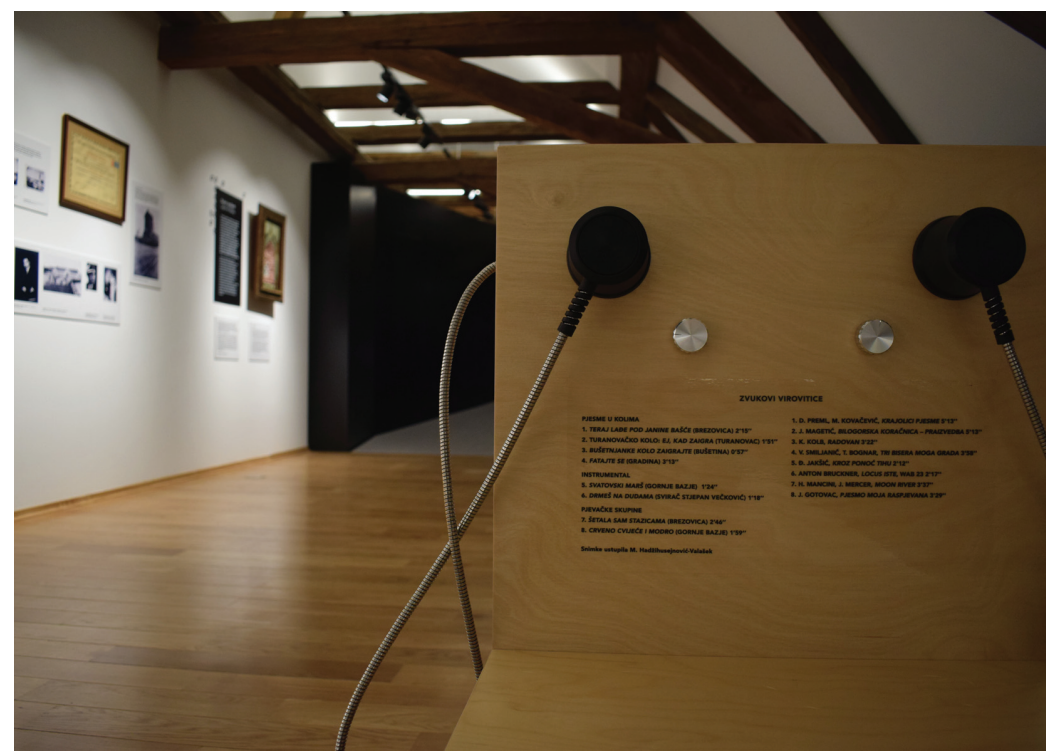

Slika 9. Interaktiv sa pjesmama. GMVT, 2019.

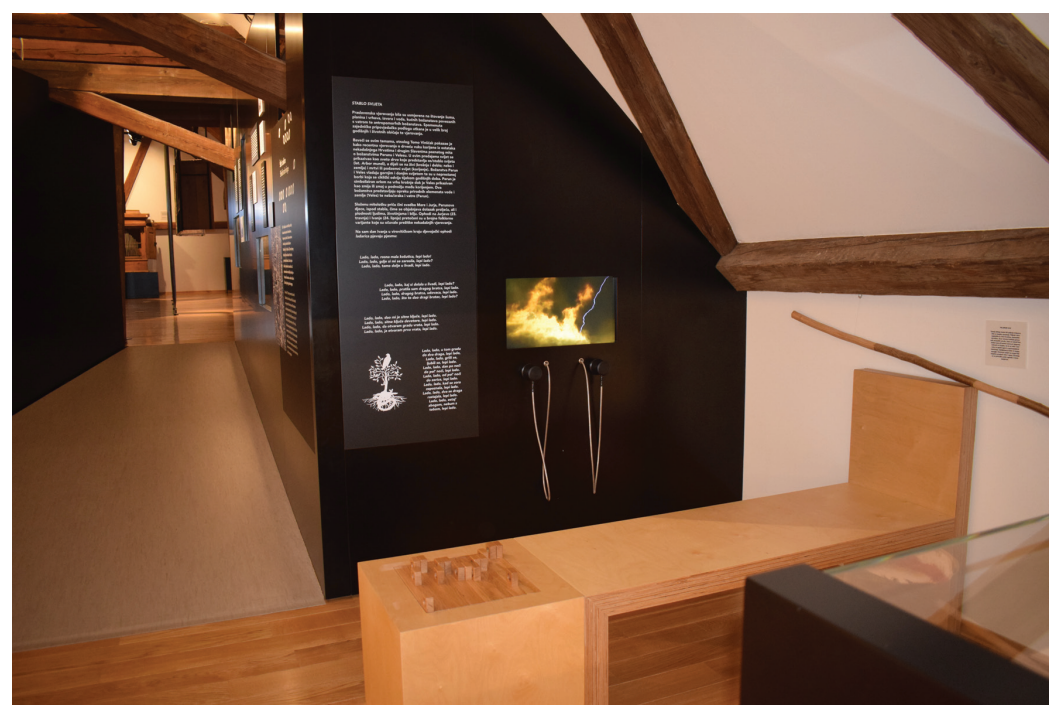

Slika 10. Video u temi Stablo svijeta. GMVT, 2019. 


\section{Ethnographic Heritage: Challenges in Museum Presentations}

\section{Summary}

The paper presents isolated examples in the preparation and realization of the latest permanent display of the Virovitica Town Museum opened in 2019. Special emphasis has been placed on the museum exhibits from the Ethnological Department, which are to portray everyday life in Virovitica and its surroundings in the $19^{\text {th }}$ and the $20^{\text {th }}$ centuries. The objective of the paper is to present museum exhibits of heritage-related significance through a new contextualization within the museum display, unified by a unique topic and a common story. The museum concept, called the Wooden Age, includes topics of wood as a material originally used from prehistory to the present day. The museum exhibits (in both direct and indirect connection with wood) are thus connected with everyday life and human activity through the topics of work, identity, money-earning, family, housing, social life, beliefs, and artistic expression. The paper further tackles museum challenges in selecting and preparing the exhibits, composing stories intended to portray material and non-material heritage, and installing museum exhibits based on museographic considerations at a protected cultural monument - the manor huse of the Pejačević family.

Keywords: permanent display; ethnographic heritage; museum exhibits.

Jasmina Jurković Petras, dipl. etn.; prof. povijesti

Gradski muzej Virovitica

Trg bana J. Jelačića 23, 33000 Virovitica

jasmina.jurkovic@muzejvirovitica.hr 